\title{
10
}

\section{Overland to Canton: The British Cultural Encounter with China}

The only worthwhile objective left for the embassy following its premature dismissal from Yuanmingyuan was the opportunity to expand British knowledge of China during its four-month journey from Tianjin to Canton. Representing only the second group of Englishmen to visit the interior of China, this aspect of the embassy has received little attention from historians apart from a 2014 article by Gao. However, Gao's arguments are contentious, especially his assertion that the men of the Amherst Embassy were permitted 'greater opportunities to explore the real state of Chinese society' than their compatriots in the Macartney Embassy (p. 570). While Gao appears to base his opinion on Amherst's statement that his embassy was permitted 'a greater degree of liberty than had been granted to any former Embassy', the evidence does not substantiate this claim (Amherst to Canning, 8 March 1817, in BL IOR G/12/197 (Reel 2) F 281). A closer reading of the accounts of the Amherst Embassy reveals that British freedom to explore towns and cities was prohibited by a series of imperial edicts whose strictness of implementation was determined on the whim of provincial officials and severely restricted by the presence of large crowds. While Staunton (1824) expressed the hope that the presence of Mandarin speakers would enable them to 'throw some new and interesting light on the moral character and condition of this singular people', he acknowledged the power of preconceived notions for strengthening, rather than correcting, existing prejudices regardless of the impact of direct experience (p. 206). Any exploration of the 'real state of Chinese society' remained impossible. 
What follows is an exploration of the British encounter with China in this phase of the embassy with a focus on its members' reactions and judgements of the country and its people.

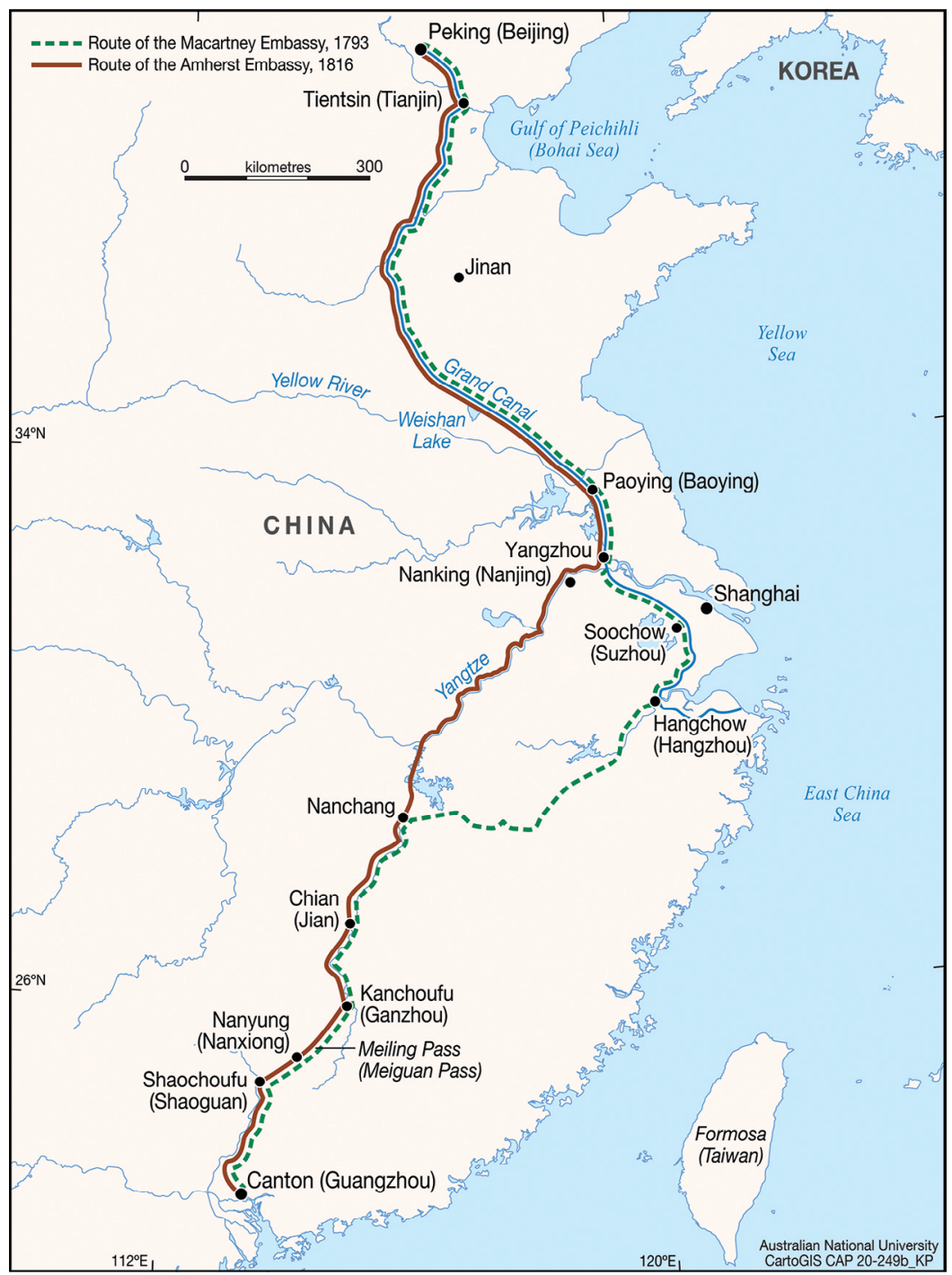

Figure 9: The routes of the Macartney Embassy (1793) and Amherst Embassy (1816).

Note: Amherst's route deviated from Macartney's by travelling down the Yangtze River to Nanking and through the Poyang Lake before rejoining Macartney's route at Nanchang and onto Canton.

Source: CartoGIS, College of Asia and the Pacific, ANU. Based on map in Cranmer-Byng (1962, p. 157). 
British perceptions of Chinese society, of course, were formed inevitably within the context of the embassy's personal standards of civilised conduct founded on good manners, appropriate behaviour and appearances. British assessments of the Chinese countryside, towns and villages were measured not only in comparison with England, but also, and significantly, with the earlier accounts of the Macartney Embassy where evidence of economic decline since that time was widely noted. Barrow's main aim in his book Travels in China (1804) of ascertaining China's place on a scale of civilisation was not a major concern for any of the Amherst Embassy's commentators. Rather, their collective British response to China was overshadowed by the Chinese insult to British honour at Yuanmingyuan, which they attempted to counter by stressing the imperative of maintaining an impressive and dignified British appearance as the embassy travelled through China.

British accounts of their journey follow a timeline of daily occurrences and detailed descriptions of the countryside and towns passed on the way. The approach of this chapter is thematic rather than chronological, and an attempt is made to portray what a British embassy would have looked like to Chinese observers and how its personnel felt and responded to the alien environment in which they found themselves. Emphasis is placed on the cross-cultural encounter with the Chinese, rather than a simple travelogue of visits to specific cities or temples.

The chapter concludes with Amherst's arrival and reception in Canton in early January 1817 and his departure on the Alceste at the end of the month. The homeward voyage saw the shipwreck of the Alceste off the coast of Sumatra and Amherst's subsequent meeting with Napoleon on the island of St Helena. The former emperor's views on the outcome of the embassy provide an alternative 'imperial' perspective on Amherst's approach to his diplomatic mission.

The embassy left Tianjin on 8 September 1816, travelling to Canton in a series of straggling convoys and reached its destination on 1 January 1817. It followed Macartney's route down the Grand Canal as far as 'Kwa-choo' (Guazhou). From there, it made a detour following the Yangtze River and proceeding through the Poyang Lake, thus traversing 280 miles (over 450 kilometres) of country not visited by the Macartney Embassy. Arriving at Nanchang, the capital of Jiangxi province, the embassy rejoined Macartney's route into Canton. The last stage of the journey was a short overland hike across the Meiling Mountains on the boundary between the provinces of Jiangxi and Guangdong. 
The cost of the embassy's journey to Canton, it has been noted, was borne by the Chinese Government. An initial fleet of 60 boats carried the 73 Englishmen and 400 Chinese boatmen, trackers and Chinese officials accompanying the embassy. Massive amounts of British luggage and stores, including crates of the bulky presents refused by the emperor (consisting of a fire engine, sedan chairs, delicate crystal chandeliers and fragile chinaware and glassware) were packed on board.

Guanghui was left in sole charge of the embassy after the early departure of Chang-wei and Yin. ${ }^{1}$ Hayne (n.d., vol. 2) described Yin coming at breakfast time to say farewell along with his staff who had been handsomely rewarded by the British. To offer their gratitude, Yin's 'underlings' proceeded to prostrate themselves before Amherst. Hayne wrote, 'The very idea of prostration [was] so repugnant to Englishmen's feelings that L. A. [Lord Amherst] could not bear to see them and would not permit it' (p. 160). The conduct of the embassy was overseen by Manchu officials, either a judge, treasurer or general, who joined Guanghui as the embassy progressed through their respective provinces (Morrison, 1820, p. 65). Reactions towards the embassy, in particular the amount of freedom permitted to its members to visit towns and roam the countryside, varied according to the disposition of the various provincial officials. Official meetings with Amherst were rare, a fact that angered the British who read this as a further insult to his status as their sovereign's representative.

Referring to events at Yuanmingyuan, Amherst wrote that the Chinese had violated 'the rules of hospitality' and he was not looking forward to the long journey to Canton (Amherst to Canning, 21 April 1817, in BL IOR G/12/197 (Reel 2) F 378). Staunton (1824, p. 205) quoted Morrison who succinctly summed up the British feeling that they were now travelling to Canton 'under the frown' of the Chinese Government. He added that 'the unwarrantable and inhospitable treatment ... the mission experienced' at Yuanmingyuan had disposed the British to 'look on surrounding objects, in some degree, with a jaundiced eye' (p. 206). Ellis (1817) thought the fact that Guanghui had been delegated to conduct the embassy to Canton

1 Both Chang-wei and Yin had left the embassy by 18 September 1817 . Chang-wei was appointed the judge of Shandong Province. Morrison (1820) said he 'owed this promotion to the Duke [Heshitai] who was himself downgraded' (p. 64). Davis (1841) spoke highly of Yin, praising his frankness and kind treatment when Amherst and his party arrived at Haidian: 'when the rest deserted us. We had formed a pretty intimate acquaintance with both of them ... and knew how to make allowances for the servants of such an autocrat as their emperor, whose single word was sufficient to consign them to death, in the event of any suspicion of a collusion with foreigners' (p. 168). 
indicated 'an additional punishment' to his dismissal from the office of salt commissioner at Tianjin (pp. 193-194). Nevertheless, Ellis hoped that new experiences would change his view of China as an 'uninteresting nation' (p. 198).

The changed status of the embassy was apparent immediately with the removal of special honours traditionally accorded to a tribute embassy. Staunton (1824) complained on arrival back at Tianjin from Yuanmingyuan, 'No [mandarin] visited ... or message of congratulations took place' (p. 145). Honours such as ornamental arches and columns of soldiers dropping to their knees in salute as the embassy flotilla passed through towns were evident, but this was in response to the presence of high-ranking mandarins accompanying the embassy rather than respect paid to the British ambassador. Abel (1818) appreciated the unique circumstances in which the embassy's journey was being conducted and how it coloured British reactions to China. He wrote:

I apprehend ... that any person travelling through a country in a hurried journey, under a suspicious surveillance, must always be unqualified to pronounce on a question that respects a whole nation. (p. 205)

Abel (1818) and Ellis (1817), who gave the fullest descriptions of China in their accounts of the embassy published in Britain, candidly acknowledged the limitations of their perceptions. Dangerously ill during the journey to Canton and largely bedridden, Abel's (1818) account 'on the progress of the Embassy, and the nature of the country through which it passed' (p. 142) was dependent largely on the reports of others, notably Morrison and Cooke. Ellis (1817) admitted also to short sightedness. ${ }^{2}$ Staunton, whose account was printed privately for family and friends, complained petulantly that the Macartney accounts had left him nothing new to say about China. He wrote:

The comparative novelty of a first discovery, are wanting on the present occasion; on which we are continuing, under circumstances which are certainly somewhat unsatisfactory and discouraging, to trace a route, which has of late been repeatedly and fully described by others. $(1824$, p. 205$)$

2 Ellis (1817) wrote, 'indeed my powers of observation of visible objects in general are very limited, partly from shortness of sight, but principally from negligence' (p. 222). Later in his journey, on 30 November, Ellis wrote, 'Orange groves have been seen this morning; the shortness of my sight has prevented me from remarking them' (p. 361). 


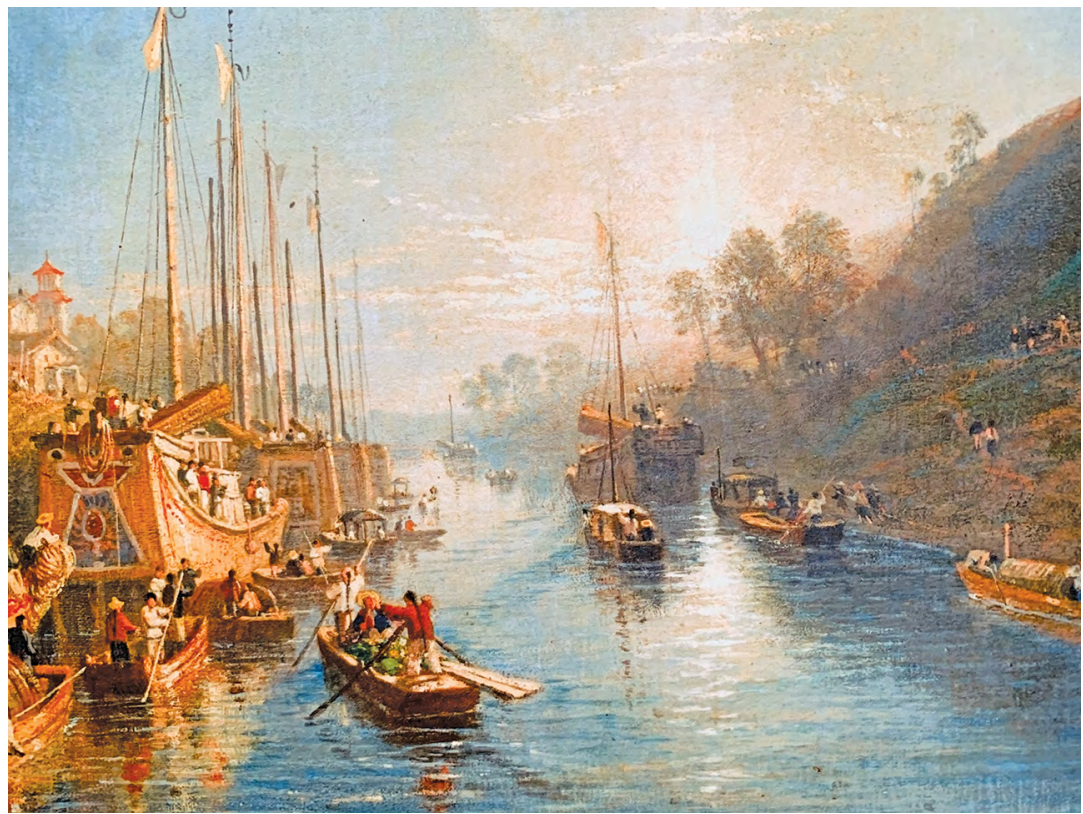

Figure 10: 'Sunrise on the Grand Canal of China', painted by the official artist of the Amherst Embassy, William Havell (1782-1857), depicting the 'British' boats moored at anchor along the Grand Canal.

Source: Image courtesy of Bonhams, Sydney, and with acknowledgment of Sphinx Fine Art, London, original owners of the copyright.

Barrow (1817a) wrote later, somewhat facetiously, that the journey down the Grand Canal from Peking to Canton was 'now nearly as well known as the road from London to Edinburgh' (p. 465). Yet, Staunton hoped the detour through Nanjing and the Poyang Lake would prove not only 'one of the most pleasant and interesting circumstances' of the voyage, but would also present the opportunity of making new discoveries (1824, p. 207). While Staunton's account of the embassy was published in 1824 for private distribution only, it seems not unreasonable to suggest that he may have published his journal for a general readership had he discovered anything new or novel about China that had not been described in previous British accounts. To have done so would have enhanced his already considerable reputation and fame as Britain's foremost sinologist by bringing his name before the wider British public.

The Macartney Embassy accounts of China, specifically Alexander's impressive and broad pictorial representation of China based on 2,000 sketches and paintings and Barrow's Travels in China (1804), which was widely referenced on the journey, had effectively established a template 
for British perceptions of the country and its people (see Legouix, 1980). Staunton (1824) wrote in the context of the British anticipation of learning the true moral character of the Chinese people at this time:

We may find that experience is not always profitable to knowledge — and that our ingenuity in adapting every thing to our preconceived notions is such, that our erroneous prejudices are often strengthened, instead of being corrected, by those facts and occurrences, which, had they been dispassionately considered, must have effected their removal. (p. 206)

Barrow's views on China, it has been noted, were scathing. The Chinese did not enjoy freedom or liberty, individualism was crushed by reverence and submission to a despotic ruler, and life was governed by ancient custom marked by filial piety of juniors to their seniors. Rationality and scientific enquiry based on experiment and observation was not only alien to the Chinese, but also the mass of the people lived under the yoke of superstition and idolatry. China's failure to interact with the wider world brought a lack of both social and commercial progress, leaving it backward and incapable of change. China, Barrow concluded, was worn out by 'old age and disease' (1804, p. 258). Henry Hayne, Amherst's private secretary, who made constant reference to Barrow's (1804) book, summed up the prevailing mood of his countrymen at the time of the Amherst Embassy. He agreed with Barrow and wrote in his diary: 'What a government to serve under-what a country to live in' (n.d., vol. 2, p. 125).

Of interest is the fact that markers of abhorrent Chinese customs described by Barrow (1804), such as female infanticide, foot binding and their habit of eating strange and unclean foods such as cats and dogs, received little attention in the accounts of the Amherst Embassy. This suggests either that they were so entrenched in the British imagination that there was no further interest in describing them, or that little evidence was available to substantiate them. ${ }^{3}$ However, other earlier British perceptions of China were confirmed. China was a 'curious' but boring place. Ellis (1817) especially thought his journey to Canton was 'dreadfully dull'. ${ }^{4}$ Havell, the embassy's draftsman, left only a handful of sketches and paintings of China, in contrast to the

3 On the subject of female infanticide, Abel (1818, p. 233) wrote that, in travelling through the country, there was not a 'sufficient number of facts for estimating the ... credibility' of the earlier estimates of 2,000 infant deaths in Peking alone noted by Sir G. L. Staunton.

4 Ellis (1817) commented that 'taking a walk was the only amusement afforded in this dreadfully dull journey' (p. 199). 
voluminous visual record left by Alexander at the time of the Macartney Embassy, thereby contributing little to enhance British knowledge of China and suggesting that he found little to inspire him.

General British impressions of China, however, changed as the embassy travelled south into more fertile, picturesque and prosperous areas of the country, and where they received more civil treatment from the Chinese authorities. Staunton learned in discussions with a military mandarin, who remembered him from the occasion of entertaining viceroy Sungyun on board the Perseverance at Whampoa in 1811, that the emperor had ordered that 'every kind of public attention and honor should be paid to the Embassy', evidenced by the rank of the great officers designated to escort the embassy (Staunton, 1824, p. 188). ${ }^{5}$ Official confirmation arrived in the form of a copy of an imperial edict, received by the British on 8 October, that instructed the officers conducting the embassy to treat it 'with all the civilities due to an Embassador'. The edict read:

The said Embassy came with the intention of offering tribute; still treat it with civility, and silently cause it to feel gratitude and awe; then the right principles of soothing and controlling will be acted on. ('Translation of an Imperial Edict addressed to the Viceroy of K'iang-nan (Jiangnan), respecting Treatment of Embassy, received October 8, 1816' in Ellis, 1817, pp. 502-503, Appendix 8)

British expectations of an open exploration of Chinese towns, however, were soon thwarted when another imperial order arrived prohibiting such excursions.

The visitors noted the vast and sophisticated network of internal commerce evidenced by the great number of grain junks returning from Peking and admired the physical beauty of the lakes and mountains while sailing down the Yangtze River, but visits to temples or 'joss houses' presented numerous examples of gross idols and Chinese superstition. The embassy read the number of dilapidated buildings and lack of new construction as evidence of economic decay, but the presence of some prosperous Chinese farmers in the southern provinces reminded them more of the dignity and industriousness of the British yeoman. Although Ellis (1817) noted some fine 'gentlemen's country-houses' on the banks of the Poyang Lake, he sought to qualify his observation: 'it being understood that gentlemen's applies only to the houses, and not to the owners' (p. 333).

5 The conversation took place on 26 September 1816. 
Contact with local Chinese was random and communication restricted, even for the Mandarin speakers. Staunton and Havell 'rambled' together whenever possible: 'We met but few of the country people on the course of our walks, and those we did meet, appeared unusually indifferent and incurious' (Staunton, 1824, p. 297). Peasants stood respectfully aside as the British passed but rarely raised their eyes from the ground (p. 297). Other social encounters were with shopkeepers and monks during visits to various temples.

China was experienced overwhelmingly from the decks of the boats that represented a British space in much the same way as modern-day tourists encounter alien cultures from the air-conditioned comfort of luxury buses or Western-style hotels. Accommodation on board was comfortable with furniture brought from England and a kitchen at the stern where cooks prepared English-style food and footmen served European wines. In their alien surrounds, British camaraderie and attitudes persisted, reinforced by regular communal dinners and the odd cricket match played on Chinese riverbanks.

Sensory historians have explained the importance of the senses in people's perceptions of an alien culture. David Howes explained in his Introduction to Empire of the senses (2005) that sensory perception is primarily the product of culture and is the major medium through which people classify and understand different societies (p. 3). The 'senses', according to Mark Smith (2007), are a product of place and especially time. Historians have noted a change in the European hierarchy of the senses during the eighteenth century where the visual, or sense of sight, defined by objectivity, logic and reason, emerged as the most important sense for classifying alien cultures (Howes \& Lalonde, 1991).

British perceptions of China experienced the country as a visual and objective encounter. Hence, notes were taken of the distant appearance of cultivated fields, housing, waterways, wildlife and farming practices. Closer to hand, the daily sight of the Chinese boat trackers pulling the boats through the Grand Canal informed the British about the condition of the lowest class of Chinese society. Ellis (1817) described these men, who were at once simultaneously 'objects of compassion and disgust', as 'deformed, diseased, emaciated, and covered with rags' (p. 251). Trackers observed later in the voyage were more presentable. Those of Jiangxi province, for example, were 'stout well looking men' who wore 'neat blue uniforms bordered with red braid'. The pleasing demeanour of the 'lower 
orders' as well as the neat and clean appearance of the general population seen at this stage of the journey reminded Staunton (1824, p. 186) of Europeans of the same class.

Chinese smells persistently caused the British great discomfort. Abel (1818) wrote on nearing Canton, 'A stranger in China rarely experiences a pleasing emotion without it being destroyed by some circumstance offensive to the senses' (p. 198). Moorings close to towns resulted in British complaints of smells and foul air, while Chinese noises were especially grating to English ears. Ellis (1817) complained that 'nothing is done in China without noise and rout' (p. 384).

Cultural curiosities constantly amused or irritated British sensibilities. The propitiation of the river spirits at local temples by the ritual slaughter of cocks by the Chinese boatmen who prostrated themselves 'before a table covered with yellow silk, ornamented with the figures of dragons' at local temples was noted (Abel, 1818, p. 147), and no doubt recalled comparisons with recent British experiences at Tianjin.

Chinese attitudes to the value of human life mortified the British. Ellis witnessed a man falling into the Grand Canal: 'The Chinese would not make the least effort to save [him] and seemed to regret ... the perseverance of one of the ambassador's guard and of our servants [who] succeeded in recovering the body' $(1817$, p. 249). British reactions to the corpse amused the Chinese who laughed at their response (Journal of Sir William Fanshawe Martin, 1817, p. 50, in BL ADD MSS 41346-41475). The Chinese reluctance to help, Staunton (1824, p. 183) explained, was due to the absurdity of Chinese law where witnesses who interfered in life and death situations were in danger of being liable to either imprisonment or torture if a fatality occurred. ${ }^{6}$

British disembarkation from the boats onto alien Chinese soil replaced the visual sensorium with those of other senses. Immersion in Chinese crowds especially ensured an acute awareness of cultural differences through the senses of smell, sound and touch. British access and freedom to 'ramble' through the countryside and towns was constrained constantly by crowds of curious onlookers whose closeness distressed them. Sensory

6 On 23 September, during the first day of travelling on the Grand Canal, a Chinese boatman fell off Ellis's boat and, despite British attempts to rescue him, drowned. The mandarin who eventually arrived to inspect the coffin ordered Chinese witnesses to kneel before him and he interrogated them as culprits (Ellis, 1817, p. 249). 
historians, such as Alain Corbin (1986), confirmed the discomforting touch of the 'alien other' in which the unease and annoyance of the 'putrid masses' make crowds dangerous. Walking through the crowded, narrow streets of Chinese towns assailed British senses affected by strange noises, smells, touches, and indecipherable dialects and signs. Volatile crowds presented a potential danger for unrest, conflict and a restriction on personal movement. The presence of Chinese soldiers, endeavouring to keep curious crowds at bay, often exacerbated the conditions in which the British found themselves. At other times, however, Chinese crowds were polite. Such behaviour, the British thought, was in marked contrast to the rudeness of the Qing court at Yuanmingyuan.

Although Amherst informed George Canning, President of the Board of Control, that his embassy was permitted greater freedom to travel around the countryside than the men of the Macartney Embassy (Amherst to Canning, 3 March 1817, in BL IOR G/12/197 (Reel 2) F 281), this view is contentious given that British access to Chinese towns was tightly controlled. Daily itineraries were planned on the basis of the flotilla arriving at its anchorage near a town late at night and departing early in the morning, thus leaving little or no time for visits. Additionally, imperial edicts were issued periodically during the journey to Canton that forbade the British from going ashore. The first was received on 10 October while the embassy was halfway through the Grand Canal. 7 Staunton (1824) wrote in response, 'the interior of towns, we are aware, [are] in some degree forbidden ground' (p. 244). Ellis (1817) added that the Chinese 'jealousy of the cities is equally ridiculous and inhospitable' (p. 250).

\section{Nanjing}

The embassy entered the Yangtze River in 50 boats on 19 October at the start of a month-long journey along a route not previously undertaken by Englishmen. The ancient capital of Nanjing was a highly anticipated stopover, especially as Macartney had not visited the city, and it was hoped that new discoveries would be made serving to inform and expand British knowledge of China. The city was currently under the rule of a viceroy who had been governor at Canton in 1809 and shown great hostility towards the British at that time (Davis, 1836/1851, vol. 2, p. 14).

7 See Appendix G. 
Some members of the embassy, led by Amherst and Staunton and accompanied by a British marine, a military mandarin and a Chinese soldier, set out to explore the town. Stopping first at a couple of 'remarkable joss-houses' containing highly decorated representations of Buddha, referred to as Fo by the British, they continued walking towards the city when they were startled by a Chinese soldier on horseback who rushed past them 'and ordered the [city] gates to be shut' (Staunton, 1824, p. 264). On being told that foreigners were not permitted to enter Nanjing, Amherst refused to leave until the gates were opened and complained of the personal insult to the dignity of a British ambassador. Crowds of local Chinese, also denied access to the city at this time, gathered. The gates remained closed despite the embarrassed pleas from the Chinese mandarin accompanying Amherst as well as Staunton's 'strongest expression' of British indignation at the gates being slammed in the ambassador's face (p. 265). A stand-off ensued. Amherst and Staunton stood firm while Ellis and Davis were ordered to return to the boats to make a formal complaint to the legate Guanghui.

Fortunately, the matter was resolved quickly. Ellis and Davis returned within an hour with news that orders had been issued to throw open the gates. Guanghui apologised for the misconduct and ignorance of the officer issuing the order who turned out to be the district's civil governor and the soldier who had 'rushed' past the Englishmen. The gatekeeper, who had followed instructions to shut the gates, was in danger of being bambooed or punished by being struck by bamboo poles, but Amherst intervened and, with some difficulty, procured the man's pardon and release. ${ }^{8}$ Amherst was invited to enter the city, but 'his Lordship refused and said he would not have stopped a day [at Nanjing] but for the wind' (Journal of Sir William Fanshawe Martin, 1817, p. 66, in BL ADD MSS 41346-41475). Guanghui intercepted the British on their return to the boats and issued a rare invitation to tea. He apologised to Amherst who reassured him that it was never his intention to contravene Chinese rules or regulations (Staunton, 1824, p. 266). Guanghui's diplomatic and cordial manner at this time impressed Staunton who thought him a man 'of sound sense and above common Chinese prejudices' and who, on the whole, 'was not

8 In contrast to the Macartney accounts, the Amherst Embassy references several occasions of 'bambooing'. Soldiers or guards who were lax in their duty and who failed to keep a proper eye on the British were punished in this way (see Ellis, 1817, p. 324). British disgust at the practice was countered by Staunton who pointed out that 'bambooing' was no more reprehensible than the cat-ofnine tails used in the Royal Navy (Staunton, 1824, p. 423). 
unfavourably disposed toward us' (p. 267). Amherst's firm stand on this occasion was seen by Ellis (1817) as initiating 'our unrestrained liberty of excursion' (p. 300), at least at Nanjing. Only a week later, however, British movements were restricted by another imperial edict prohibiting them going ashore.

Earlier Jesuit accounts had described Nanjing's famous white porcelain tower, but Ellis noted that it was 'useless and unpleasant both to myself and to those who may chance to toil through these pages' to describe it further (p. 303). Nanjing was depicted as consisting of 'four principal streets ... through one of the larger a narrow canal flows, crossed at intervals by bridges of a single arch' (p. 303). British attempts to climb a nearby hill to enjoy the view of the countryside were interrupted by a crowd that grew in number from a couple of hundred to thousands of people surrounding the sightseers. Plans to visit adjoining temples were shelved as Ellis and his party faced the challenge of forcing their way back to the boats. Once back in the secure and ordered space of 'home', Ellis reflected on the reasons for China failing to incite British interest, let alone admiration, despite its antiquity. Significantly, he made an important distinction between Chinese antiquity and the classical antiquity of Western Europe:

In viewing this city, [Nanjing], striking from its situation and extent, and important from its having been the capital of an immense empire, I felt most forcibly the deficiency of interest in everything relating to China, from the whole being unconnected with classical or chivalrous recollections. Here are no temples, once decorated, and still bearing marks of the genius of Phidias and Praxiteles; no sites or forums once filled with the eloquence of Cicero or Demosthenes, no plains once stained with the scared blood of patriots, and heroes; no, it is antiquity without dignity or veneration, and continuous civilization without generosity or refinement. (p. 305)

Ellis's colleagues agreed with his assessment, which reflects both their ignorance of Chinese history and literature as well as the influence of a classical education in providing upper-class Englishmen with their historical and literary frame of reference for classifying culture. China, Davis (1841, p. 4) thought, had been civilised when Europe was still a barbaric society, but the country had never progressed due to its resistance to foreign commerce and technological improvement. Chinese submissiveness to one man, Davis thought, equated to a mechanical obedience best described as a 'control over animals' (p. 3). 
Guanghui paid Amherst a long visit at this time that was notable for its informality. The legate, according to Ellis (1817, p. 307), was 'unusually communicative' and proceeded to tell the British about the public life of the emperor. This rare piece of intelligence on the Chinese court grabbed even Barrow's attention and he referred to it later in the Quarterly Review (Barrow, 1817a, p. 478). The 'Son of Heaven', Ellis (1817) reported:

is [also] a victim of ceremony; he is not allowed to lean back in public, to smoke, to change his dress, or in fact to indulge in the least relaxation from the mere business of representation. It would seem, that while the great support of his authority is the despotism of manner, he himself is bound with the same chain that holds together the political machine; he knows freedom in his inner apartments, where probably he consoles himself for public privations by throwing aside the observance of decency and dignity. (p. 307)

\section{Havell Goes Sketching}

William Havell, the embassy's artist, left only a handful of sketches and paintings of China. His body of work did not contribute any new or unique representations of the country or its people in contrast to the impressive and broad pictorial representation of China produced by Alexander at the time of the Macartney Embassy. His work was not used to illustrate any of the accounts of the Amherst Embassy and Ellis's journal, published in 1817, was illustrated with aquatint plates based on drawings by Charles Abbot. While at Nanjing, however, Havell displayed an interest and appreciation of Chinese sculptures seen in a local temple that was not shared by his compatriots.

British preconceived assessments of Chinese art forms in general, and religious art forms in particular, were governed by images represented on Chinese porcelain and lacquerwares that flooded into Britain from Canton during the chinoiserie craze throughout the eighteenth century. Images of Chinese deities on these wares portrayed the Buddha as a portly, laughing character, whose depiction was geographically and representationally removed from its true context as sculptures made for the tomb or temple (see Rawson, 1992, p. 165). Havell was not concerned with the symbolism of the 'representations of the divinities' he found in the temple at Nanjing but focused instead on the form and composition of the images. These delighted him because they were 'very superior 
to any thing ... he had imagined, Chinese art could have produced' (Staunton, 1824, p. 271). His astute, educated eye recognised artistic skill and represented a very different assessment of Chinese religious art from the usual British abhorrence of the gross forms of Chinese 'idols' and animal forms found in Chinese temples. ' Chinese sculpture, perceived universally by Englishmen as an inferior and primitive art form compared to Western aesthetics founded on Greco-Roman classical traditions, had found an unexpected admirer. Unfortunately, Havell was unable to complete his assignment as large crowds of curious locals interrupted his view and impeded his sketching. Staunton's (1824) assessment of the crowd's behaviour on this occasion, however, was laudatory, and he drew an analogy with British crowds, where:

A solitary Chinese, while surrounded by an English mob, would have been rather ... hazardous ... and if made by a foreigner, in Turkey or Persia, would probably have been expiated by his instant destruction. (p. 272)

Reflecting on the sculptures at the temple at Nanjing, Ellis (1817) wrote:

On viewing the works of art of the Chinese, whether painting, drawing, engraving, sculpture, or architecture, I am surprised that they should have stopped where they have done; there were but a few steps to make, and they would have got into the high road of good taste; as it is, they are grotesque and uselessly laborious. (p. 310)

This conclusion reflected Barrow's stadial theory of civilisation expounded in Travels in China (1804) where he sought to ascertain China's status. China's natural progression in the arts, traced to antiquity, suddenly stalled. No further progress had taken place due to Chinese arrogance and belief in its superiority, which had prohibited embracing any foreign innovations that may have assisted its progress and improvement. This view also correlated nicely with Barrow's much-quoted assessment of Chinese innovation: 'they can be said to be great in trifles, whilst they are really trifling in everything that is great' (1804, p. 355). Ellis (1817)

9 Grotesque stone figures of animals guarded the piers along the Grand Canal, where highly decorated temples with ornamental roofs were noted by the British near the city of 'Tong-chang-foo' (Ellis, 1817, p. 249). 
had the last word, not only on Chinese art, but, on China in general: 'It has been said, that there is nothing new under the sun, certainly there is nothing new in China; on the contrary, everything is old' (p. 310). ${ }^{10}$

Staunton and Amherst, meanwhile, climbed the summit of the hill in Nanjing and gazed on the view of the surrounding countryside where little evidence was seen either of a sizable population or the fact that Nanjing had once been a great imperial city. The men of the Amherst Embassy, however, had at least discovered 'the actual state of this celebrated city'. Staunton (1824) pointed out:

Although the gates of Pekin had been shut against us, those of Nan-kin at least had yielded to our summons, and thus the original and most ancient capital of the empire, which had been visited, I believe, by no former Embassy, fairly laid open to our curiosity. (p. 271)

\section{General British Views of China}

British accounts of Chinese life were, inevitably, cursory. City streets were 'composed entirely of eating houses' and crowded with barbers who skilfully shampooed their customers on street corners (Abel, 1818, p. 134). At least six imperial edicts were imposed as the British travelled to Canton. These were posted on city walls and houses and throughout city streets. Staunton (1824) recorded on 30 October that there were three edicts regarding the embassy pasted on the walls of a house within sight of the English boats: 'One of them was written in characters so large, as to be legible from our boats by means of a telescope' (p. 285). The British were prohibited from entering city limits and, if they did, the local population was ordered not to talk or laugh with them and women were told to hide. Shopkeepers were not allowed to sell them goods and the sale of Chinese books was prohibited. Manning, on a visit to Datong in early November, set off on his own and visited a bookshop where he managed to select some volumes that were stacked up on the shop counter, but a stranger appeared and ordered the sale be stopped (Staunton, 1824, p. 316).

10 Ellis (1817) commented that the best Chinese art dated from the Ming period and that the 'tartar conquerors of China would seem to have communicated the barbarism without the energy of their ancestors' (p. 380). 
The British did manage to purchase some local souvenirs during their travels. These consisted mainly of small pieces of chinaware, specifically tea cups with covers, destined, presumably, for an English mantelpiece. ${ }^{11}$ Chinese shopkeepers showed a discerning ability to distinguish between the gentlemen of the embassy who were charged higher prices than the members of the band, while Chinese soldiers accompanying the British shoppers 'winked at the shop-keepers to increase their prices' (Hayne, n.d., vol. 2, p. 127). Service in some towns was excellent. The very civil and well-behaved shopkeepers of Guazhou were praised by Staunton (1824): 'They served us, and tied up and delivered the parcels just as a respectable grocer would do in England' (p. 249). Staunton purchased some tea on this occasion, while Havell bought a roll of paintings at a picture shop although these were 'indifferently executed' (p. 249). The shops of Wuhu in the province of Anhui, Ellis (1817, p. 314) noted, were excellent and would not disgrace those found in the Strand or Oxford Street. Some sold European knives and bales of woollens stamped with the Company logo. Porcelain shops were extensive, but the British were unable to purchase any pieces because of the large crowds following them and the fear of shopkeepers that their stock might be damaged (p. 190). Hayne (n.d., vol. 3) described one scene where some in a crowd were:

noisy and frolicsome amongst themselves and mischievous, throwing over stalls, pulling down signs, and they pushed one of their comrades down on a pile of coarse crockery-ware and enjoyed the joke at the expense of the poor shop-keeper. These are the sedate Chinese! (p. 14)

The presence of the imperial edicts referred to earlier, however, operated to restrict any meaningful contact with Chinese locals and were interpreted by the British as evidence of the 'contemptuous and despotic indifference to our comforts, which animates the sovereign of these dominions' (Staunton, 1824, p. 287). Hayne (n.d., vol. 3) recorded that the general who officiated over the embassy while in Nanjing had informed the British that in the past some 'Tartars passing thro' the Country had grossly violated decorum with their women' (p. 7). Similar precautions were now taken with the British, but their lack of interest and good conduct, whereby they 'did not even notice the females', had resulted in a relaxation of some

11 Staunton earlier informed his mother of a gift from the Hong merchant Puankequa of some chinaware of 10 cups and covers of a 'very pretty light pattern which will do well enough upon [your] mantle piece' (Staunton Letters, 18 March 1811). 
of the rules (p. 3). A more practical reason, in Hayne's view, was the need to secure city streets against the onslaught of the immense curious crowds that gathered and followed the Englishmen, although an edict posted in the city of Wuhu expressly forbade the British 'carrying away with us any women or children' (p. 13).

Despite the edicts, some worthwhile social encounters did take place. Staunton visited a Chinese school where a group of eight to nine year olds of the poorest class were reading aloud and learning by heart the Shee-shoo and She-king. ${ }^{12}$ Staunton gave the teacher a black lead pencil and some English paper with the names of the children written in Chinese and English; graphite pencils were a European invention and would have been a novel gift for a Chinese child. ${ }^{13}$ While unconvinced of the value of rote learning, Staunton was very impressed with Chinese attitudes towards the value of education. Discipline was not harsh and the children were described as enjoying their time at school (Staunton, 1824, p. 305). Davis (1836/1851, vol. 1) quoted Morrison regarding the Chinese regard for education: 'In China there is much to blame, but something to learn. Education is there made as general as possible, and moral instruction is ranked above the physical' (p. 240). Davis thought this state of affairs resulted from the 'industry, tranquillity, and content' of the Chinese people (p. 240).

Apart from walks in the countryside and visits to towns and temples, the British also spent time playing cricket, which, according to Hayne (n.d., vol. 3, p. 68), was undertaken without seeking official permission, which was unlikely to have been granted. Jeffrey wrote that the carpenter 'made us some bats from the Camphor wood and from this time whenever we came to a good piece of ground we had a game of cricket'. 'The Chinese', he added, 'thought we were all gone mad' (Jeffrey Amherst, n.d., n.p.). The sight of energetic English gentlemen running around the fields of China contrasted with the sedentary behaviour of the Chinese upper classes who 'seldom mount a horse' and on whom the 'benefits of walking' were lost (Davis, 1836/1851, vol. 2, p. 35). Davis concluded that, 'Nothing surprises ... Chinese gentlemen more than the voluntary exertion which Europeans impose on themselves for the sake of health

12 The Sishu (The Four Books) and the Shijing (The Book of Poetry).

13 Graphite pencils were made by the Germans and English. During the Napoleonic Wars, the supply of British graphite to France was stopped. A French chemist created pencil leads by mixing powdered graphite with ground clay and firing it, a process still used today (see Blaxland, 2008, p. 6). Amherst used a graphite pencil for many of his notes. 
as well as amusement' (p. 35). Cricket matches attracted large crowds of Chinese spectators who ringed the field. 'The Chinese', Staunton (1824) wrote, 'soon ascertained enough of the game, to be sensible of the necessity of keeping a respectable distance' (p. 368).

\section{British Lack of Access to Chinese Society}

Lack of contact or access to Chinese domestic life remained the greatest disappointment for the British. Chinese domestic architecture closed off any glimpse of family life as compounds were hidden from view and rendered the British passive observers of China. Davis (1841, p. 183) described the 'dead walls in front of dwelling-houses, which were always secluded within an inner court'. Ellis (1817) saw some scenes of home life portrayed on glass paintings at Nanchang, but the only other exposure to Chinese domestic rituals were street processions connected with weddings or funerals witnessed in the streets of Chinese towns (p. 352). Ellis lamented, 'I only regret that our situation precludes all hope of seeing any [other] domestic ceremonies' (p. 203). Opportunities for a deeper understanding of the Chinese national character were thus denied to the British. Abel (1818) wrote:

Persons travelling in a country in which they are looked upon by the government as objects of jealousy, and by people as beings in all respects inferior to themselves, must have continually to contend with prejudices likely to defeat their attempts at forming a correct estimate of the inhabitants. (p. 232)

Any access to the higher ranks of Chinese general society, corresponding to the social status of the gentlemen of the embassy, was impossible. Abel affirmed:

With the higher or better informed classes of society, for they are essentially the same in China, we had very little social intercourse that was not purely official or ceremonious; and on all these occasions found them so cased in the armour of form that it was impossible to reach their natural character, or to depend on their information as the simple statement of matters of fact. (p. 232)

British access to the 'middling class' was confined to shopkeepers, or those encountered as part of the crowds in towns and cities, and Abel lamented the fact that these occasions provided little opportunity for judgement on the state of Chinese society (p. 233). During an earlier walk in the 
countryside along the Baihe River, Abel had encountered a group of 'handsomely clothed' Chinese women who, with the arrival of some Chinese soldiers, 'hobble[d] off as fast as their crippled and stunted feet could carry them' (p. 88). A few women at Nanchang defied imperial orders and looked at the Englishmen (Ellis, 1817, p. 353). Ellis noted that their painted faces presented a 'carnation tinge to the complexion' and their fine eyes 'though angularly shaped were together tolerably attractive' (p. 353). Hayne (n.d., vol. 3) suspected that these were ladies of 'dubious virtue' (p. 29). British appearances, Abel noted (1818), also made an impact on the Chinese:

We were to these people as the inhabitants of another world. Our features, dress, and habits were so opposed to theirs, as to induce them to infer that our country, in all its natural characters, must equally differ from their own. 'Have you a moon, and rain, and rivers in your country?' were their occasional questions. (p. 131)

Ordinary Chinese were sometimes very friendly to the British. Villagers helped Abel with the collection of plant specimens, while some members of the embassy established a strong rapport with their boatmen who were a great source of gossip on the embassy's progress. Thus, the British were told that Guanghui's reluctance to travel in rough weather was due to his 'small liver' that made him timid and afraid (Hayne, n.d., vol. 3, p. 24). ${ }^{14}$ On a couple of occasions, military mandarins invited the Englishmen onto their boats for refreshments. Ellis (1817) related that he and the young midshipman Charles Abbot were invited on board a boat of a military mandarin 'for the usual purpose of looking at us':

Abbot, as the youngest, was the principal object of his attention, and [our host] amused himself by dressing [Abbot] in Chinese clothes: he seemed to live in great familiarity with his servants, and put my hat on to excite their merriment; I, in return, took his cap, and the buffoonery was complete. (p. 211)

Abel's (1818) account included several occasions where he interacted with ordinary Chinese in the time before he fell ill. Removed from the pressures of official business, Abel spent time mingling with itinerant barbers and hawkers who set up stalls at the sites where the embassy docked to cater to the Chinese on the boats. He visited a food stall 'arranged with great neatness and order' whose cook was a 'plump and sleek old man, naked

14 Here the British are mistaken. Rather than the liver, the boatmen were probably referring to Guanghui's gallbladder. In traditional Chinese medicine, a small gallbladder makes one cowardly. 
to the waist' and whose complexion suggested he had 'passed all his life within the influence of a furnace' (p. 90). The cook insisted on showing Abel all the secrets of his art and begged him to 'partake of its produce', but Abel found the hot sesame cakes too oily for his taste (p. 91).

Abel was also asked to join some Chinese soldiers camped on the riverbank who were sitting around red lamps suspended from three sticks, smoking pipes and playing dominos. Time was spent comparing the respective size of their hands with Abel, much to everyone's amusement, while Abel's gilt buttons and fine linen shirt were much admired. Abel declined some offerings of clothing but accepted some white cloth badges inscribed with Chinese characters worn by the soldiers around their necks.

\section{Keeping up British Appearances: Dinner Time}

Amherst maintained embassy morale during the long journey through China with formal dinners marking British ceremonial occasions held on shore whenever the terrain permitted the setting up of tables. Hayne (n.d., vol. 2, pp. 151-152) referred to Saturday night drinking sessions held in accordance with the 'old ship custom of drinking on Saturday night at sea to the wives, sweethearts and absent friends'. These were elaborate affairs governed by strict protocols of etiquette characterised by cordial conduct consisting of refined manners, politeness and fine conversation that defined rank and personal civility. A formally laid dining table complete with fine silverware, cutlery, crockery, crystal glassware and a countless range of serving dishes, all brought from England, added to the opulence and formality of the occasion. The strong social bonds resulting from shared experiences of China evinced at these times by the 20 'gentlemen' of the embassy reaffirmed British identity and values and endorsed the perceived superiority of British civilisation in the alien environment of China (see Elias, 1939/2000, pp. 5-6).

The sensory anthropologist Lisa Law has written on the power of food to 'articulate national identity' by evoking memories of the taste, aroma, and texture of home $(2005$, p. 236). Its potency derives from its classification as a category of 'cultural separateness' (Tannerhill, 1995, p. 230). A variety of fine produce was provided to the British by their Chinese hosts. In northern China, these consisted of sheep, bullocks, pigs, fowls and a variety of vegetables and fruits. On reaching the Yangtze River and 
Poyang Lake, the British were supplied with vast quantities and varieties of vegetables, deer, game fowls, geese, ducks and fresh fish, as well as white grapes, apples and mandarins. Breakfasts, given information from British cookbooks of the time, consisted of rolls, cakes, eggs and fruits. Dinner, served at four o'clock in the afternoon, was the main meal of the day. Three cooks were in charge, namely, two British cooks and Staunton's Cantonese cook. Normal meals took place on individual boats among small groups of only two to four, attended by several staff.

English cookbooks of the period suggest the menus that may have been offered during the Amherst Embassy. Food historians have noted the change that took place in British cuisine at this time where the preference was for bland, honest food, cooked simply and without the embellishment of fancy sauces thought to disguise the integrity of original ingredients (Turner, 2004). ${ }^{15}$ French cuisine, notable for sliced meats or fricassees smothered in sauces, was not to British taste. Southern European cooking, characterised by dishes of greasy food, reeking with garlic and swimming in olive oil, was considered most unpalatable (Margaret Visser as quoted in Howes \& Lalonde, 1991, p. 127). The similarity of this continental style of cooking with Chinese cuisine familiar to the members of the Amherst Embassy was noted by Davis (1836/1851, vol. 2), who wrote that 'Chinese cookery has a much nearer resemblance to the French than the English' (p. 25). British preference for hearty soups such as a country-style vegetable broth with shredded cabbage was eminently suited to the ingredients supplied to the embassy. Soups were followed by meat dishes consisting of hams, braised goose and roast chicken. Accompanying the main dishes was a variety of entrees such as boned crumbed chicken breasts, sautéed fish, and boned game of pheasant and stuffed partridges in aspic. ${ }^{16}$

The sensory experience of the British meal enjoyed by the embassy members functioned momentarily to transform the Chinese environment into a part of Britain (Law, 2005, p. 226). Smells of food cooked in the British manner wafted across the landscape, while strange sounds of cutlery scraping plates would have puzzled Chinese witnesses. The accompanying music provided by the ambassador's band assisted the cultural transformation, as well as attracting large crowds of Chinese.

15 Turner (2004) wrote that British tastes by the nineteenth century had shifted to 'simpler and more local flavors ... the new ideal was that food should taste of itself' (p. 301).

16 This menu is an adaptation of a formal dinner given for the Prince Regent at the Brighton Pavilion in January 1817. It is referred to as an indication of dishes that may have been prepared at the time of the Amherst Embassy (see Tannerhill, 1995, pp. 298-300). 
People climbed up surrounding trees to see the table laid and hear the band more distinctly. Curious mandarins often visited the British at table where their presence caused an annoying, hot and stuffy atmosphere; an alien presence that might spoil the ambience of the occasion. The band, however, was culturally adaptable and took advantage on occasions to entertain both the British and Chinese. Staunton (1824) described its playing on shore at the time when the embassy was due to enter the Yangtze River:

Our band played on the bank opposite Lord Amherst's boat, for some time during the afternoon, and drew together a considerable audience of mandarines as well as country people, who all appeared, by their manner and attention, much pleased with our music- The band played, among other pieces, the Chinese tune of Moo-lee-wha, which the natives readily recognised. (p. 249) $)^{17}$

A constant source of amusement for the British during their travels through China was the shabby military appearance of the Chinese soldier. The victors over Napoleon were unimpressed and critical of what they saw. Primitive weapons of bows and arrows, rusty flintlock rifles and effeminate uniforms resembling dresses attested to China being an unwarlike nation (Ellis, 1817, pp. 225, 267). The British passed some forts made up of temporary structures of matting and 'rudely painted, so as to have the appearance of brick or stone at a distance' that reminded the visitors of a production seen in country theatres and a 'good laugh' was had by all (pp. 225, 267). Davis, whose account of the embassy was published after the First Opium War, was a harsh critic of the primitive nature of Chinese weaponry and the childishness of its soldiers and officers. The Chinese commander of Amherst's boat, for example, was fond of a game where an Englishman was invited to blow in his face, after which he turned his face away, but then turned around and 'ran in and seized his antagonist by the leg to upset him' (Davis, 1841, p. 178). Davis believed this action indicated the importance of bodily strength and dexterity in the Chinese military, but thought it also proved 'the low state of the art of war among them' (p. 178). ${ }^{18}$ Nonetheless, some Chinese

17 Molihua or 'Jasmine Flower'.

18 Davis's (1841) account contained his opinion on the strategic importance of Tianjin for any future British engagement: 'It must be viewed as the first object of attack to any force which should make an attempt in the neighbourhood of the capital, and try the strength of Chinese troops in that quarter. Its vicinity to the sea, and its vast importance as the depot for grain and salt, render it extremely obnoxious to foreign invasion' (p. 189). 
military officers were singled out for acting with great civility. One lent John Griffith, the embassy's chaplain, his horse so that Griffith could ride back to the entrance of the junction of the Grand Canal, which he had missed (Staunton, 1824, p. 193).

Even Ellis admired a military parade seen on the beach at Anqing in Anhui province. Four hundred and fifty Chinese soldiers, decked out in 'full armour, drawn out on the beach with their officers in their stations, and their colours, music, tents, \&c, duly arranged and displayed', saluted the British boats (Staunton, 1824, p. 317). Davis (1841), however, played down the occasion. The soldiers made a 'good theatrical show' and reminded him more of an opera chorus than 'men whose trade was slaughter' (p. 225). In his view, the small marine guard accompanying the Amherst Embassy could have taken Tianjin with ease (p. 89). This early assessment of the primitive state of the Chinese military was reinforced as the embassy travelled through China.

Insulting Chinese behaviour remained a constant source of irritation for the British. Morrison, acting on Amherst's orders, wrote a letter of complaint to Guanghui, notable for harbouring a veiled threat:

This morning - when His Lordship went out of his boat, there were native soldiers who several times rudely stood and intercepted his path. [Further] as Mr. Ellis passed Chin-tazin's boat, his servants rudely began to laugh. It is seriously apprehended that to treat us who are visitors in a foreign country with such rudeness, may provoke some unpleasant occurrences, and therefore Your Excellency is now [requested] to take some means to prevent so unfortunate an affair. (Correspondence During the Embassy to China (September 1815 - September 1817), in BL IOR MSS EUR F 140/38 (a))

Although Morrison was aware that Chinese officials who acted civilly towards the British exposed themselves to the ill will of the mandarins, concern with external appearances befitting the status of the embassy drew complaints when their dignity was thought to be compromised (Correspondence During the Embassy to China (September 1815 September 1817), in BL IOR MSS EUR F 140/38 (a)). Chinese officials acted most 'unhandsomely' when complaints were made about Guanghui being assigned a superior boat to Amherst. Morrison informed Amherst in a private letter that they 'deserved any trouble it may occasion them' 
(Morrison to Amherst, n.d., in BL MSS EUR 140/38 (a)). He continued in a passage that succinctly summarises much of the British frame of mind during their journey to Canton:

There was at first on the part of the Chinese who spoke to me a disposition to be rudely familiar and assuming. Having withstood the Emperor and the Duke at the door of the Court, it would perhaps be wrong to submit to the gross neglect of the Legate ... at the extremity of the Empire. (Morrison to Amherst, n.d., in BL MSS EUR 140/38 (a))

Troubles also arose over incidents involving quarrels between the members of the band and some Chinese. Morrison told Amherst, 'some of our people - the band it is supposed-have struck some Chinese, which gave occasion to ... ill-natured [complaints]' (Morrison to Amherst, n.d., in BL IOR MSS EUR 140/38 (a)). Accordingly, Amherst imposed a curfew on the band and the British servants who were not allowed to leave their boats after dark without special permission (Staunton, 1824, p. 251). On the whole, however, the lower orders of the embassy acted with 'a very fair character' and there were only a few instances of drunkenness and quarrels among themselves (p. 360). The earliest Chinese complaint about bad British behaviour on the journey to Canton occurred as the boats were entering the Yangtze River. An investigation revealed, however, that this was 'a boyish piece of fun of Jeffrey Amherst's in pushing a boy into the water' (Hayne, n.d., vol. 2, p. 248).

British respect for Guanghui increased on the sad occasion of the death of a British marine who slipped on the deck of Morrison's boat and drowned. Morrison informed Amherst, whose boat was moored some distance away down river, that:

The Chinese, by order of the Legate, afforded every assistance, \& at my request, during the night, cut a grave-stone the following Epitaph: 'The Tomb of Millidge, one of the Body-guards of the British Embassador; Nov 11. 1816'. This is a translation. The words were in Chinese. (Morrison to Amherst, n.d., in BL IOR MSS EUR F 140/38 (a) $)^{19}$

19 Morrison also informed Amherst that a death certificate had been issued in order for it to be registered with the Qing court and the viceroy at Canton. It read, 'On the 11th Nov 1816, one of the British Embassador's Body-guard named Millidge, aged 31 years, in passing from the head to the stern of the boat, the plank being rendered slippery by rain, lost his footing; fell into the water \& was drowned'. Staunton (1824, p. 320) incorrectly referred to the marine as 'Millage'. 
Guanghui's response at this time was praised by Staunton (1824, p. 321) and described as 'very civil' and expressing 'great concern'.

Apart from observing the Chinese people in the towns and villages they visited, the British took the opportunity of mapping their route through the Yangtze River. Amherst informed Canning that because this was country 'hithertoo unexplored' by any Englishman:

I was anxious to preserve the best memorial of it which our very limited means would allow: and this has been effected by the industry and accuracy of Mr. Charles Abbot, the eldest son of the Speaker of the House of Commons ... who accompanied me on my landing in China. He had prepared as detailed a map \& memoir of the country as could be accomplished without the aid of some of the most essential instruments, and with occasionally, but little time for observation. (Amherst to Canning, written aboard the Caesar at sea, 21 April 1817, in BL IOR G/12/198 (Reel 2) F 256-257)

\section{The Arrival of the Alceste at the Pearl River}

The HMS Alceste arrived at Lingding Island, outside of Macao, on 2 November after a journey of almost three months exploring the Gulf of Bei Zhili, the eastern coast of Korea and the Ryukyu Islands. ${ }^{20}$ Captain Maxwell, following the precedent of the HMS Lion at the time of the Macartney Embassy, was under orders from the Admiralty to proceed to Whampoa to refit in preparation for Amherst's arrival. Dispatches were received on board announcing the failure of the Amherst Embassy, followed soon after by an edict sent by the viceroy of Canton prohibiting the Alceste from entering the Pearl River to meet Amherst. Amherst, it seems, was expected to find his own way to the British ships anchored outside the Pearl River, travelling by a back passage 'without suffering to call, much less to stop, at Canton' (Barrow, 1817a, p. 479).

20 Restrictions of space prohibit discussion of the Ryukyu Islands in this study. For the account of these, see M'Leod (1818/1820) and Hall (1840/1865). 
Maxwell received conflicting orders from the Canton Government. It was initially confirmed that a passport and pilot would be assigned to the Alceste, permitting the ship to proceed to Whampoa, but this order was countermanded three days later by a senior mandarin sent by the viceroy. Maxwell told the mandarin that an imperial edict had specified that the Amherst Embassy be treated with the same respect as that accorded to Macartney, and that consequently he was allowed to go to Whampoa. The mandarin offered no response. Maxwell remained calm in the face of the mandarin's 'rudeness' but responded in a tone and manner that, according to Basil Hall (1840/1865), 'made the Mandarin's button wag on top of his bonnet' (p. 69). On being asked by the mandarin if the Alceste was carrying any cargo that would have required the ship being registered as a trading vessel, Maxwell replied:

Cargo, did you say!-Powder and shot, sir, are the cargo of a British man-of-war! Did you see his Majesty's pendant flying at the mast-head? If you did not, I desire you will take a good look at it on your way to Canton, where you may tell the Viceroy you have seen a flag that has never been dishonoured — and please God, while it waves over my head it never shall. (as quoted in Hall, $1840 / 1865$, p. 69)

Several days passed with no resolution of the stand-off. Maxwell gave orders on 12 November for the Alceste to approach the mouth of the entrance to the Pearl River where she was surrounded by 17 Chinese war junks and the shore batteries were seen making full preparations to repel the ship. The junks 'beat their gongs, fired guns, and threw up sky-rockets, to give the alarm', but no damage ensued (M'Leod, 1818/1820, p. 104). Maxwell, deciding to take matters into his own hands, loaded one of the quarterdeck guns and personally fired it at the Annanhoy fort, destroying an outside wall and invoking from the crew of the Alceste 'three roaring cheers' (p. 104). ${ }^{21}$ The result, according to Hall (1840/1865, p. 71), was 'instantaneous and most ludicrous'. Maxwell told him that the Chinese 'fell flat on their faces ... like Persians at sunrise'.

21 M'Leod (1818/1820) added that this was a deliberate action taken by Maxwell who was aware that, in the event of the Chinese 'demanding who fired, instead of those who ordered, or of seizing upon any innocent person, he might fully place himself in the situation of being individually responsible for all consequences'. Staunton (1822, p. 313) added later that by this act Maxwell placed the whole weight of responsibility on himself. 


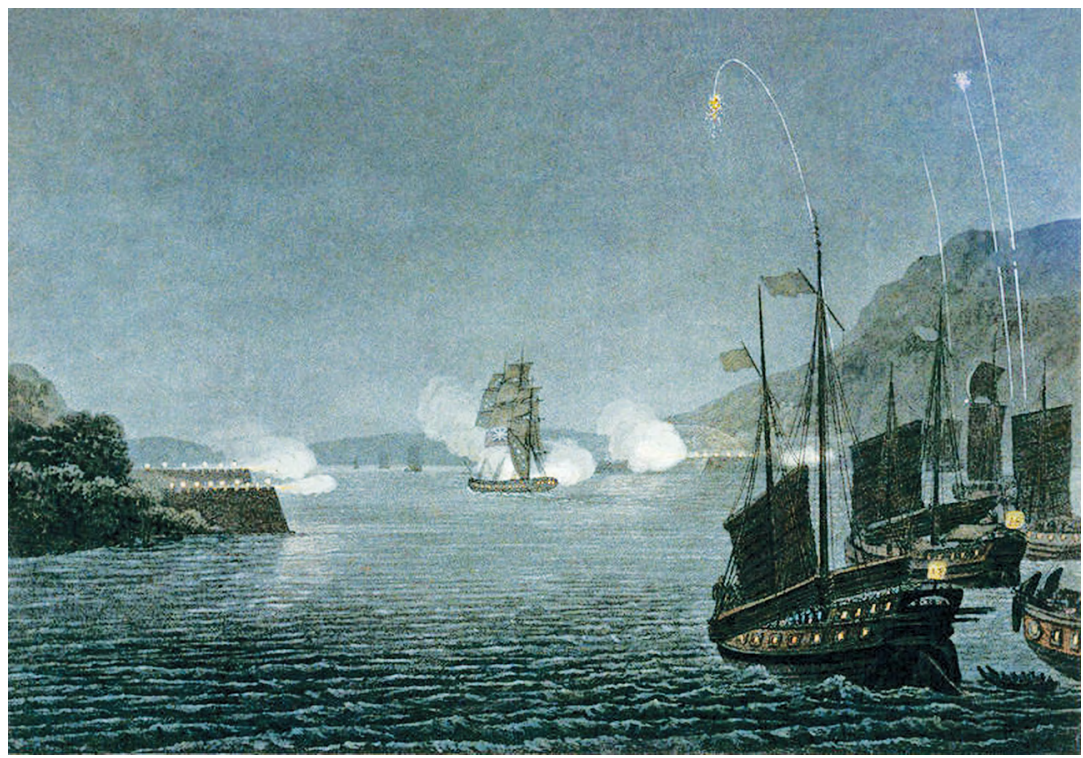

Figure 11: The engagement in 1816 of the HMS Alceste under Captain Sir Murray Maxwell with the Chinese fortresses on the Bocca Tigris, both of which he immediately silenced.

Note: Drawn by John M'Leod, surgeon on board the Alceste. Engraved by Dubourg and published and sold in 1818 by Edward Orme, Bond Street, London.

Source: Image from Wattis Fine Art, Hong Kong, and now in the author's collection.

The breeze sprung up soon after, and the Alceste sailed through the Bogue on its way to Whampoa. Captain Maxwell later received an official explanation that the junks did not fire at the Alceste in anger but were merely saluting the ship. The British read this as a flagrant lie but were afterwards gratified to learn that Maxwell's actions had resulted in 'a remarkable improvement in the condition of foreign residents' at Canton (Hall, 1840/1865, p. 75). The Indiaman General Hewitt, which had been involved in a serious altercation with the Canton authorities and prevented from loading teas for her return voyage to England on the grounds that she was a tribute ship, was now allowed to take on cargo. ${ }^{22}$ The Alceste, anchored at Whampoa, also began taking on provisions and making preparations for Amherst's return expected in late December.

22 The General Hewitt had arrived at Lingding Island on 12 September 1816 but was refused permission to travel up-river to Whampoa to load tea. The Hong merchants refused to deliver the Select Committee's letter to the viceroy and the suggestion that Captain Campbell would go in person to deliver the letter was received with much alarm as he had not been granted permission to travel to Canton. Following the committee's suggestion that tea would be loaded at Lingding, the General 


\section{Amherst's Return to Canton and Reception}

The local people grew ruder and the crowds became less interested in the British as the embassy procession approached Canton. Progress was slow and difficult through the rapids and shallow streams as the trackers struggled to keep the boats under control. The picturesque countryside was conducive for walking and Staunton (1824) was amused to see 'pinnacles of hills dotted with parties of Englishmen' from the embassy (p. 395). The mountains separating the British from Canton were seen on the morning of 16 December and, three days later, preparations involving 3,000 men were made to cart the baggage over the mountain pass. Amherst was transported in a 'glazed palanquin' carried by 12 soldiers and the commissioners travelled in palanquins borne by six soldiers. The servants, guards and band members were each carried in small open chairs by two bearers (p. 439). Nights were spent at rest houses where graffiti on the walls revealed the names of the Dutch embassy of 1795 and some of the Amherst party added their signatures (p. 445). Five days out from Canton, the flags on the British boats were changed to 'tribute flags' (Ellis, 1817, p. 399). Lines of handsome soldiers were drawn up as the British passed and Amherst was moved to a superior boat, while Guanghui was thought to be increasingly cordial and civil in his manner. A small white cottage, passed on 30 December, reminded Ellis of England 'to which indeed all our thoughts begin now to turn' (p. 404).

\section{Some British Conclusions on China}

While many of Barrow's (1804) earlier assessments of China were confirmed by the members of the Amherst Embassy, especially that the Chinese were a 'frowzy people', some new judgements were made at this time. Ellis (1817) commented on Chinese affection for their children and thought that 'their civil institutions' enforced the 'reciprocity of good

Hewitt was surrounded by Chinese war junks. An impasse lasted for several weeks. The ship eventually reached Whampoa on 23 October after a series of visits by some mandarins and the committee's letters not being received by the Hoppo resulted in the committee sending a naval officer to force his way into Canton to deliver a letter to the viceroy. A compradore from the British Factory was arrested for having been complicit in the officer's visit. The stand-off continued into November and was not resolved until the compradore was released and Captain Maxwell had forced his way up the river (Morse, 1926/1966, vol. 3, pp. 265-269). 
conduct' (p. 204). Evidence of Chinese familial love was illustrated by Chang-wei's 18 -year-old son having to return home to live with his mother 'as she could not endure being separated from him'. This, Ellis thought, showed that Chinese 'ladies', as distinct from women of the lower classes, had 'their full share of influence in Chinese families' (p. 204).

The reports of the Amherst Embassy confirmed Macartney's earlier views on the clear distinction between the Manchu or 'Tartars' and the Han Chinese. Macartney wrote that China consisted of:

Two distinct nations ... the Chinese and the Tartars, whose characters essentially differ (notwithstanding their external appearance be nearly the same) and whose minds must naturally be differently bent by the circumstances which respectively govern them. They are both subject to the most absolute authority that can be vested in a prince, but with this distinction, that to the Chinese it is a foreign tyranny; to the Tartars a domestic despotism. (Cranmer-Byng, 1962, pp. 221-222)

Macartney thought that China's failure to progress higher on the scale of civilisation was due to the impact of the Manchu conquerors who had held China back while their European contemporaries were 'every day rising in arts and sciences' (pp. 221-222). In Davis's (1841) view, the 'Tartars' were too proud to learn from foreigners, in contrast to the progressive and inquisitive British who never missed an opportunity to study them (p. 109). 'Knowledge', for the British, was 'power', reflecting the value they placed on intelligence at a time of an expanding maritimebased empire that was global in nature. Davis further noted the coarse manners of the 'Tartar' military officers, who he thought were also 'illiterate' (p. 203). He added that, 'The very inferior consideration of the military, as compared with the civil mandarins, is purely Chinese, and appears under Tartar despotism, as a singular anomaly' (p. 203).

The British did have some positive experiences in their dealings with Qing officialdom. Thus, the 'gentlemanly behaviour' of an officer from Shandong province was found to be 'extremely pleasing' (Ellis, 1817, p. 264). Specific praise was accorded to the escort who accompanied the embassy through Jiangxi province due to his 'conversation [which] was full of expressions of the highest consideration' of England and with 'humble allusions' to China (Staunton, 1824, p. 391). Staunton praised the civility and attention shown by local officers on the Yangtze River for their efforts 
in overseeing the British boats (p. 239). Even Davis (1841) approved of Chang-wei, the Han Chinese junior legate, who had accompanied the embassy since it first arrived off Dagu:

The ease and good breeding of the better sort of Chinese, when they are on friendly terms, is very striking, and by no means what might be expected from the rigid nature of their ceremonial observances. (p. 191)

Chang-wei's 'real politeness' and pleasant manner resulting from a daily familiarity with the British represented a state of mutual admiration between him and the senior members of the embassy. Chang-wei sat with the British at dinner, although he did not much 'relish' English cooking, and expressed his warm admiration of 'the blunt integrity and straight-forwardness of the English character' (p. 191). Such, however, were exceptional relationships. The other Manchu mandarins involved with the embassy displayed little or no interest with either Amherst or the commissioners. The British saw their arrogance and disinterest as indicative of a regime clinging to past glories and grounded in the belief that China was the centre of the universe. The presence of highly educated Mandarin-speaking Englishmen in the Amherst Embassy, eager to learn as much as they could about China, presented a unique opportunity for the senior mandarins of the Qing Government to learn more of the outside world in general and of Britain in particular. The opportunity, however, was not taken up. Instead, Amherst, the British complained, was treated by the senior mandarins with the most 'wilful neglect ... of all the common courtesies and rights of hospitality' due to the envoy of a foreign state (Staunton, 1824, p. 408). Staunton, in particular, was scathing of the lack of honours accorded to Amherst in contrast to those paid to the Chinese conductors of the embassy. He concluded that the 'complimentary display' showed to the embassy was 'as worthless, as their military shew is contemptible' (p. 409). Amherst was insulted late in the journey when the conductors of the embassy were given a three-gun salute on passing a military post while he was ignored. Morrison was instructed to send a formal note of complaint regarding this 'piece of inattention' (p. 425).

Staunton sought to sum up the attitude of the ordinary Chinese people towards the British. Their predominant feeling, Staunton thought, was 'an overpowering curiosity, perfectly inoffensive and good-humoured', which contrasted with the 'contemptuous and malignant spirit' displayed to the 
British by the Cantonese (p. 409). Ellis's (1817) assessment of China, on the other hand, reflected ambiguous British feelings of the country resulting, in part, from the failure of the embassy and the nature of its reception at Yuanmingyuan. He concluded:

However absurd the pretensions of the Emperor of China may be to universal supremacy, it is impossible to travel through his dominions without feeling that he has the finest country within an imperial ring-fence in the world. (p. 323)

\section{Return to Canton}

On New Year's Day 1817, seven miles from Canton, the members of the Amherst Embassy noted the ambassador's barge from the Alceste, flying the royal standard and bearing Captain Maxwell and Metcalfe, approaching them at a rapid rate followed by 21 other boats of the British ships anchored at Whampoa (Jeffrey Amherst, n.d., n.p.). Two lines of barges belonging to the Lyra and the Indiamen were lying downstream waiting to escort Amherst to his lodgings prepared at 'the temple of Ho-nan' (Haizhuangsi), situated on the banks of the Pearl River opposite the British Factory, which had been 'splendidly fitted up' in a European fashion by the order and expense of the Chinese Government (Staunton, 1824, p. 479). Hayne (n.d., vol. 3) commented that the Chinese 'bishops' had been 'cajoled and bribed' to give up their own apartments (p. 115). ${ }^{23}$ 'The paraphernalia of idol worship', Abel (1818) wrote, 'had given place to the commodious furniture of an English home' (p. 206). Jeffrey added that the Chinese had consented 'to the removal of their Josses from the part of the temple which we inhabited and they were stowed away in a lumber room' (Jeffrey Amherst, n.d., n.p.). Hayne (n.d., vol. 3) elaborated that the 'gods and goddesses were either out of doors or shut ... up in cupboards' that were now replaced by 'stoves, and British furniture' (p. 115). The temple had been transformed into 'a palace fit for a British Embassador' (p. 115). Charles Abbot wrote a long letter to his father dated 2 January 1817 :

23 Hayne (n.d., vol. 3) added that the gateway or 'portico' to the temple was guarded on each side by gigantic statues representing Chinese gods, or guardians of the temple. These were painted and gilded in the 'most gawdy colours and with hideous fierce countenances' (p. 117). 
Here I am comfortably settled in an arm-chair by the fire-side, in a Chinese temple, which has been appropriated to the Embassy during their stay here, and been made to look like an English house by the kindness of the gentlemen of the British Factory. (The Hon. C. Abbot to his father, Lord Colchester, Canton, 2 January 1817 , in Colchester, 1861, vol. 2, pp. 13)

Amherst and the embassy dined that evening at the British Factory. The function was attended by over 100 people, all of whom were English apart from the American Consul. It was a splendid evening with toasts after dinner, complimentary speeches and songs (Hayne, n.d., vol. 3, p. 117). 'Every heart was glad' and the Englishmen 'experienced in the heartiness of the reception a pleasing contrast with the pretended hospitality of the Chinese' (Ellis, 1817, p. 407). Amherst took the opportunity to scrupulously maintain the appearance of His Majesty's ambassador and informed George Canning later in his official report that it was only now that he was able to do so (Amherst to Canning, 21 April 1817, in BL IOR G/12/197 (Reel 2) F 358).

Amherst had a final formal engagement to attend, namely, an imperial banquet held for the delivery of the letter from the Jiaqing emperor to the Prince Regent. Informed that he was expected to kowtow, he replied he would bow on receiving the letter. On 3 January, a letter from the mandarins notified the British that the ceremony had been downgraded to a reception for the delivery of the letter and that the prostration ceremony was dispensed with.

An unauthorised copy of an imperial edict dated 6 September addressed to the viceroy of Canton found its way into British hands the following day. Its wording differed from other edicts and blamed the failure of the embassy at Yuanmingyuan on the actions of the British ambassador and commissioners, specifically, for not observing the laws of politeness toward their own sovereign' who had sent presents at great cost and across great distance to indicate his respect and obedience to the emperor. A reception for the British was to be held where the viceroy was to instruct Amherst of his failure 'to lift [his] eyes to the face of Heaven' and to give thanks to the emperor for the benefits received while in China (see Ellis, 1817, pp. 505-506, Appendix 10). The British found themselves in a predicament. Decisive action was required to stop the viceroy from making an insulting address, but care also had to be taken not to reveal how a copy of the edict had come into their possession (p. 411). 
The reception was held on 7 January in a large yellow tent constructed outside the temple. Preceded by the band and the marine guard, Amherst and his party, dressed in their ambassadorial robes and uniforms, made a splendid appearance. The emperor's letter, housed in a bamboo tube covered with yellow silk, was placed on a small sedan chair carried by 36 bearers. The viceroy handed the letter to Amherst who received it with a profound bow and handed it to his secretary, Henry Hayne. Jeffrey noted in his journal, 'The viceroy seemed astonished at the little respect with which the Imperial letter was handled, but said nothing' (Jeffrey Amherst, n.d., n.p.). Entering a side apartment, Amherst and the viceroy held a brief discussion during which the mandarin asserted in a haughty tone that the British had benefitted from Chinese trade for about 100 years (Amherst to Canning, 21 April 1817, in BL IOR G/12/197 (Reel 2) F 362). He claimed that Britain could not 'dispense with the commodities of China', whereupon Amherst replied that these were not indispensable and that both Britain and China mutually benefited from the trade, which was equal and reciprocal (Amherst to Canning, 21 April 1817, in BL IOR G/12/197 (Reel 2) F 363). Both men then adjourned to the tent for fruits and refreshments. Jeffrey described a 'most ridiculous scene' that took place as the viceroy and Amherst walked to the tent:

The Viceroy and ambassador walked together at the head of the Party, but the former wishing it to appear that he was of the highest rank endeavoured to get a little ahead of my father, but my father perceiving his object stepped out also, until our arrival at the tent put an end to the race. (Jeffrey Amherst, n.d., n.p.)

The British read Amherst's performance in front of the viceroy as a moral victory. Abel (1818) described the mandarin as a 'character of cunning' who endeavoured to adopt an overbearing attitude but who soon 'grew pale, and his eyes sunk under the stern and steady gaze of the English Ambassador' (p. 210). ${ }^{24}$

Father Lamiot, the only French missionary still at Peking, had sent a Latin translation of the emperor's letter (Amherst to Canning, 21 April 1817, in BL IOR G/12/197 (Reel 2) F 364). Its contents were the same as noted in the earlier copy where the encounter at Yuanmingyuan was attributed to the pertinacious and successful refusal of the ambassador

24 Barrow, in his review of Abel's book in the Quarterly Review in 1819, commented: 'We did not think that Lord Amherst could assume so formidable a look-at all events we are inclined to think that the presence of Captain Maxwell and the recollection of the guns of the Alceste ... were not without their due share in "blanking the once bold visage" of the viceroy" (p. 83). 
and Commissioners to attend the emperor, under the absurd pretext of sickness' (Ellis, 1817, p. 413). It also contained some assertions, referred to as 'falsehoods' by Abel (1818), that Macartney had kowtowed and that Amherst had at first promised to do so, but afterwards refused. Abel concluded, 'We felt no regret in learning that with a government so faithless, the delivery of the letter had terminated the Ambassador's official intercourse' (p. 211).

Amherst had a busy social calendar at Canton. He paid a visit to Guanghui who was 'cheerful and chatty' and who sent a communique suggesting that some of the British presents might still be accepted by the emperor. The British believed that this indicated that 'the Imperial court is not without apprehension of the possible consequences of the abrupt dismissal of the Embassy' (Ellis, 1817, p. 414). A decision was taken to decline all such suggestions as conciliating the emperor would add to British humiliation. Amherst was also invited to a dinner held in his honour by Chun-qua, one of the principal Hong merchants. Ellis hated it. He complained of the infernal noise of the 'sing-song' and instruments and noted the mandarin buttons worn by the Hong merchants were purchased at a high price to provide immunity from government punishments (p. 419). Guanghui, in contrast, enjoyed a breakfast held at the British Factory where 'his manner and conduct was perfectly unembarrassed, easy, affable, and cheerful: he seemed to feel himself among friends, and lost no opportunity of shewing attention to those within his reach' (p. 414).

\section{Amherst's Departure from China}

Amherst prepared to leave Canton on 20 January 1817. Guanghui paid a call in the morning 'and seemed quite sorry to leave us' (Jeffrey Amherst, n.d., n.p.). Amherst, accompanied by all the boats of the Company's ships, was given three cheers as he left the pier. Ellis (1817) wrote:

It was impossible to hear [these] without strong emotions. There was an awful manliness in the sound so opposite to the discordant salutations and ridiculous ceremonies of the nation we were quitting. (p. 421)

The viceroy, who was watching the departure from a distant boat moored in the river, sent Amherst his card, but Amherst chose to ignore it. The viceroy's action, the British thought, was not meant as a point of civility but, rather, as concern to witness the departure of the embassy. The Alceste, 
moored at Whampoa, was reached at three o'clock in the afternoon. The man-of-war was decorated with her colours and her yards were manned (Jeffrey Amherst, n.d., n.p.). Amherst informed George Canning that, on boarding the Alceste, 'I considered my intercourse with the Chinese Authorities as at an end' (Amherst to Canning, 21 April 1817, in BL IOR G/12/197 (Reel 2) F 374). ${ }^{25}$ A parting dinner was held in the evening for Staunton who was travelling to England separately on the Indiaman Scaleby Castle. Three days later, the Alceste arrived at Macao after passing the forts whose personnel paid the 'utmost respect' with the guard turned out and saluting as the ship passed (Amherst to Canning, 21 April 1817, in BL IOR G/12/197 (Reel 2) F 374). ${ }^{26}$ The governor of Macao sent his apologies for not receiving Amherst as all appointments had been suspended because a state of mourning was declared for the late queen of Portugal. Metcalfe suspected that this was deliberately timed to coincide with Amherst's arrival so that the Portuguese 'may boast to the Chinese' that the British ambassador had received 'no mark of attention from them' (Metcalfe to Amherst, Macao, 21 January 1817, in BL IOR MSS EUR F 140/38 (a)). Amherst was also informed that several Chinese troops had entered the settlement and had set up camp opposite the intended landing place of the embassy at Macao, ostensibly as a mark of respect. On 28 January 1817, Amherst left Macao and 'finally took leave of the Coast of China' (Amherst to Canning, 21 April 1817, in BL IOR G/12/197 (Reel 2) F 374).

\section{Postscript}

The Alceste and Lyra left Macao together, but separated at Manila from where the Lyra sailed for India. A little after seven o'clock in the morning of 10 February 1817, the Alceste hit a reef in the Gaspar Straits off the coast of Sumatra. Jeffrey wrote to his sister:

The shock which it gave was tremendous; I was walking up $\&$ down in my father's Cabin $\&$ could hardly keep my legs ... there was a large hole in her [the Alceste's] bottom ... water had already filled one store room ... the bumping was dreadful, as whenever

25 Amherst's notes and letters, and subsequent career, reveal that he chose not to pursue any further interest in China.

26 The Asiatic Review (August 1818, p. 192) quoted the Madras Courier for 9 February 1818: 'In China all was quiet. The Chinese were busily employed about rebuilding the fort that the Alceste bombarded with such effect. They are also building new ones in different parts of the river'. 
the ship rolled, she struck again against one of the rocks ... all the pumping was useless. (Jeffrey Amherst to his sister, 2 March 1817, in BL IOR MSS EUR F 140/230)

The boats were hoisted out and loaded with 'such provisions as were not wet' and set off with the members of the embassy to a small uninhabited island situated three miles away (Jeffrey Amherst to his sister, 2 March 1817, in BL IOR MSS EUR F 140/230). ${ }^{27}$ Jeffrey wrote that Captain Maxwell joined the group the following day, where it was decided:

That the barge with my father \& the gentlemen of the Embassy should start at three o'clock for Batavia; each gentleman was allowed to take a change of linen ... We did not start till six o'clock, \& had some difficulty in clearing the rocks. We were thirty three persons in the barge, \& fifteen in the cutter which came with us. We had the good luck the second day to have some rain by which we got some water to drink. We arrived on the fourth day at Batavia, and the first sight of the [British] ships was the most cheering sight we ever saw. (Jeffrey Amherst to his sister, 2 March 1817, in BL IOR MSS EUR F 140/230) ${ }^{28}$

The 200 Englishmen, and the boatswain's wife, who remained on the island were in constant danger of attack by large numbers of Malay pirates who had already burnt the wreck of the Alceste and threatened an assault on the island. Help reached the besieged group 12 days later with the arrival of an Indiamen, Ternate, that scared off the Malays. Maxwell's conduct throughout the calamity was widely praised in England and Ellis (1817) commended him for his 'firmness and commanding character ... [which ensured] sufficient security for the maintenance of discipline' (p. 452). Maxwell was later called before a court martial for the loss of the Alceste but was completely exonerated.

\section{A Meeting with Napoleon on St Helena}

The members of the embassy set sail for England from Batavia in the Indiaman Caesar. Returning via South Africa, the Caesar arrived at St Helena on 27 June 1817 where Amherst met Napoleon. Napoleon's views on the fate of the Amherst Embassy are not mentioned in Ellis's

27 The island was situated 240 miles (386 kilometres) from Batavia.

28 Abel's plant specimens, collected under the orders of Sir Joseph Banks and destined for Kew, were mistakenly discarded at this time for a change of linen for one of the members of the embassy. 
(1817) account, but are instead recorded in a book written by his English surgeon, Barry O'Meara, published in 1822. Napoleon was very knowledgeable on the impasse of the kowtow and displayed a most pragmatic attitude to the issue. Amherst, he thought, should have bribed the mandarins: 'If a million of francs had been given to the first mandarin, everything would have been settled' (as quoted in O'Meara, 1822, vol. 2, p. 69). ${ }^{29}$ The embassy, in Napoleon's view, had not been sent on behalf of British national honour; rather, it was 'as an affair of merchandize' sent on behalf of 'the tea-merchants in England' (p. 44). Therefore:

Advantages might with great honour be purchased. Besides, when you send ambassadors to those barbarians, you must humour them and comply with their customs. They do not seek you. They never have sent ambassadors in return for yours, nor asked you to send any. (p. 44)

Napoleon told Amherst that the consequence for his embassy, in which $£ 100,000$ pounds had been 'thrown away' and ill blood between the British and Chinese had resulted, was caused 'by a ridiculous misunderstanding' (p. 178). Amherst had been informed 'by bad advisors' and had proceeded to act under the misguided apprehension that an 'ambassador represented' his sovereign. Napoleon, as a former emperor himself, made it clear that he believed Amherst's rank equated to that of the princes or the 'grandees' of the court, who, in China, were expected to perform the kowtow before the emperor. The emperor, therefore, 'had a right to require it' (p. 176). Further, Amherst was chastised on his presumption whereby he attempted 'to regulate the etiquette of the palace of Pekin by that of St. James's'. England and Russia, according to Napoleon, should:

instruct their ambassadors to submit to the ko-tou, upon the sole condition that the Chinese ambassador should submit in London and Petersburg to such forms of etiquette as are practised by the princes and grandees. (p. 178)

Napoleon did not consider the kowtow a humiliating act, but thought that in respecting the customs of another country, 'you make those of your own more sacred' (p. 178). He had, of course, missed the fundamental point of Chinese tributary diplomacy. The kowtow for Napoleon, it appears, was

29 Gabriel de Magalhaes, in his account of the Dutch embassy sent to China in 1655, acknowledged that the Dutch bribed the viceroys of Canton and a number of Chinese officials, especially the Manchu president of the Board of Rites, which almost secured Dutch success in their objectives (see Kops, 2002, pp. 568-569). 
just theatre or mere ceremonial, and it meant nothing beyond an act to please the emperor. In this respect, the British had more in common with the Chinese than they did with Napoleon. Both knew the kowtow was an act of profound political significance, changing forever the basis of the relationship between the actor and the recipient. They did differ, however, in the role of the ambassador. For the Chinese, the role of an ambassador was not simply to pay respect or deliver messages, but to portray the submission of his sovereign. In any event, the victors over Napoleon were in no mood to be lectured. The Literary Gazette commented in its November 1817 issue:

The conversations with the Ex-emperor are rather hacknied, and we shall only offer one remark on the dicta ascribed to him, - that if he had sent an Embassy to China, he would have taken care to dispatch a person who would have observed all the prostrations required. We trust the difference between the Prince Regent of England and a Corsican adventurer will always be held a sufficient answer, at least in this country, for our not being prone to pursue exactly the same course; and it may be further added, that what would have been a disgrace to a British nobleman, might have been unobjectionable in one of the revolutionary dignitaries of the new order.

Staunton had the last word on Napoleon's views. He wrote to Amherst from St Helena after a conversation with the governor, Sir Hudson Lowe, on the issue of the kowtow: 'I shall only say that it will not be the first time that England and Bonaparte have differed upon matters of State policy' (Staunton to Amherst, St Helena, n.d., in BL MSS EUR F 140/38 (a)). 
This text is taken from Britain's Second Embassy to China: Lord Amherst's 'Special Mission' to the Jiaqing Emperor in 1816, by Caroline Stevenson, published 2021 by ANU Press, The Australian National University,

Canberra, Australia.

doi.org/10.22459/BSEC.2020.10 